\title{
Study on Legal Issues of Ecological Resources Protection in Qinghai Province
}

\author{
Guanghan Zhou \\ School of Hubei University for Nationalities, Enshi 445000, China
}

373925797@qq.com

\begin{abstract}
In recent years, taking the Inner Mongolia Autonomous Region as an example, the economy is developing rapidly, and the development and utilization of resources is the industry pillar. While the exploitation of resources has serious damage to the environment on the grassland and desert. The traditional production and living way of ethnic minorities depends on a good ecological environment to a certain extent. As a result, once the ecological environment is destructed, it will produce a serious threat to the survival and development of ethnic minorities. The provisions of the law of ecological compensation of mineral resources in minority areas are studied, the mineral resources ecological compensation in the national and local laws and regulations are sorted out, and ecological compensation problems in various fields are evaluated, which are mainly the legal provisions problems. In addition, the method of factor analysis is adopted to analyze the existing problems of ecological compensation for mineral resources development. What's more, the implementation of ecological compensation for mineral resources in minority areas are summed up, and whether these gains can be used for ecological compensation is discussed. At last, this paper attempts to put forward the idea of perfecting the legal system of ecological compensation system of mineral resources in China from several angles.
\end{abstract}

Keywords: Ecological resources, rights and interests protection, ethnic minorities.

\section{Introduction}

With the continuous development of industrialization, mineral resources exploration and development has become one of the most important factors that affect the grassland environment. It is necessary to re-examine the environmental protection and ecological compensation of the grassland. In some areas, in the exploration and development of mineral resources, driven by the huge economic benefits, the grassland environmental protection is left behind, and the game between economic interests and ecological interests, rights to survival and development is continuing [1]. As a result, it results in that the majority of the public and the government pay attention to the problem of mineral resources development, environmental protection and ecological compensation. Thus, it is urgent to solve a series of problems, including environmental protection, ecological compensation, and protection of minority interests and so on in the mineral resources exploration.

This paper analyzed the legal regulations of laws on ecological compensation in different fields in the national and local levels, and summed up the deficiencies and shortcomings of ecological compensation mechanism of mineral resources in China. In addition, we focused on the legal regulations of ecological compensation for mineral resources in ethnic minority areas, and opened the balance mechanism between economic interest, ecological interest, and the survival and development interests. At last, we intend, through the establishment of ecological compensation system for mineral resources in ethnic minority areas, to promote the rational exploitation and utilization of mineral resources, and sustainable development of environmental protection and national minority area, and to play the scientific and reasonable role of ecological compensation to promote social fairness and justice. 


\section{An analysis of the existing laws and regulations of ecological compensation for mineral resources in Minority Areas}

Over the years, in the areas of economic and social development of ethnic minorities and ethnic minority areas, China has adopted a number of preferential policies to promote the development of regional and ethnic groups, mainly including the following aspects:

(1) Resource exploitation and processing area

The article twenty-eighth of the law of the People's Republic of China stipulated that the autonomous organs of the national autonomous areas, in accordance with the provisions of the law and the unified planning of the State, give priority to the rational exploitation and utilization of natural resources that can be developed by the local authorities [2].

Article fifty-sixth stipulated that the State, in accordance with the unified planning and market demand, give priority to rational arrangements for resource development projects and infrastructure projects in the national autonomous areas. The State shall appropriately increase the proportion of investment and policy bank loans in major infrastructure investment projects.

The article sixty-fifth stipulated that the State, in the development of resources and the construction of the national autonomous areas, should take care of the interests of national autonomous areas, make arrangements in favor of economic construction in ethnic autonomous areas, and take care of the local minority national production and life [3]. The State shall take measures to give certain benefit compensations to the national autonomous areas that export natural resources.

(2) Environmental protection

Article forty-fifth of the Autonomous Law stipulated that the autonomous organs of the national autonomous areas shall protect and improve the living environment and ecological environment, prevent and control pollution and other public hazards, and realize the coordinated development of population, resources and environment.

Article sixty-sixth provided that the State organs at higher levels should include the major ecological balance, environmental protection and comprehensive management projects in the national autonomous areas into the national economic and social development plan for unified deployment. For the national autonomous areas that make contributions to the ecological balance and environmental protection, the State shall give them certain benefits [4]. Any organization or individual shall take effective measures to protect and improve the local living environment and ecological environment, and prevent and control pollution and other public hazards in the development and construction of the national autonomous areas.

The "fifth provisions" stipulated that, the superior people's government and its functional departments, in the formulation of long-term planning for economic and social development, should listen to the suggestions of national autonomous areas and ethnic work departments. In addition, they are supposed to, according to the characteristics and needs of national autonomous areas, support and help national autonomous areas to strengthen infrastructure construction, and human resources development, expand the opening up, adjust and optimize the economic structure, and rationally make use of natural resources. What's more, it is necessary to strengthen ecological construction and environmental protection, accelerate the development of economy, science and technology, education, culture, health, sports and other undertakings, so as to achieve a comprehensive, coordinated and sustainable development.

\section{Thoughts and countermeasures on improving the ecological compensation system of mineral resources in Minority Areas}

China's mineral resources and tax are mainly the mineral resource tax, mineral resources compensation fees, mining rights fees, mining rights price and so on. These taxes are the interests that can be owned by the central and local governments in the development and utilization of mineral resources. The study in this part starts from the various taxes and fees collection purpose, statutory purpose, tax rate, and actual amount, analyzes which has ecological compensation properties, and 
which can be used for ecological compensation. In addition, according to the existing ecological compensation theory, source and application of funds of ecological compensation for mineral resources are analyzed. The following table shows the taxable products and tax margin stipulated in 1994.

Table 1. The taxable products and tax margin stipulated in 1994

\begin{tabular}{|c|c|c|c|c|c|c|c|c|}
\hline $\begin{array}{c}\text { Tax } \\
\text { items }\end{array}$ & $\begin{array}{c}\text { Crude } \\
\text { oil }\end{array}$ & $\begin{array}{c}\text { Natural } \\
\text { gas }\end{array}$ & Coal & $\begin{array}{c}\text { Other } \\
\text { nonmetallic } \\
\text { ores }\end{array}$ & $\begin{array}{c}\text { Black } \\
\text { metal } \\
\text { ore }\end{array}$ & $\begin{array}{c}\text { Nonferrous } \\
\text { metal ore }\end{array}$ & $\begin{array}{c}\text { Solid } \\
\text { salt }\end{array}$ & $\begin{array}{c}\text { Liquid } \\
\text { salt }\end{array}$ \\
\hline $\begin{array}{c}\text { Tax } \\
\text { margin }\end{array}$ & $8-30$ & $2-15$ & $0.3-5$ & $0.5-20$ & $2-30$ & $0.4-30$ & $10-60$ & $2-10$ \\
\hline
\end{tabular}

Although a great progress in ecological compensation for mineral resources have been made, there are still lots of problems. In order to solve these problems, some effective countermeasures are put forward, in which only the major three aspects are introduced.

\subsection{Legal form}

"Ecological Compensation Regulations" drafting group leader, deputy director of the national development and Reform Commission Du Ying pointed out that, recently, it is necessary to strengthen the researches on major issues, including the connotation and extension of ecological compensation and the compensation standard, compensation funding sources, relationship between stakeholders of rights and obligations, and legal responsibilities [5]. In addition, the overall idea and legislative framework should be established.

Now, the main problems needed to be solved mainly contain the following aspects: the problems that the overall framework of "Ecological Compensation Regulations" involves, including, to determine the compensation object, appropriate compensation standard, funding sources of the compensation standards, fairness of ecological compensation, ways to realize the maximum ecological compensation funds efficiency, and necessity and feasibility of imposing ecological compensation tax.

It should be refined in the legislation of ecological compensation for mineral resources in ethnic minority areas, or principled provisions in ecological compensation regulations, or formulation of ecological compensation regulations. However, since that the ecological compensation for mineral resources in minority areas is wide-ranging, the most ideal state is to stipulate the ecological compensation regulations in ethnic minority areas. Considering the history and reality, it is supposed to focus on standardizing the compensation obligation of developers of mineral resources [6]. It aims at ensuring minority rights and interests in the development of resources and adequate compensation, so as to exercise the language rights and cultural rights and to achieve sustainable development. In addition, regulations of ecological compensation for minorities area need to be taken into account, so as to play the initiative and enthusiasm of the protection of the ecological environment in ethnic areas.

\subsection{Legal protection of entity rights of ecological compensation for mineral resources in Minority Areas}

The difficulty of ecological compensation is the most elements of production. Whether it is capital or labor, they are separable, and it is feasible to gradually increase the amount of investment in production. However, as a complete system of life, ecological resources cannot be put into production one by one, which can only play a role as a whole in production. This kind of "integrity" or "scale" of ecological resources makes it difficult to compensate under the condition of market economy [7]. First of all, the integrity of ecological resources makes it difficult to carry out the property rights allocation and definition. Although we can define the property rights of forests, land, rivers and other natural resources, on the whole, they are a part of ecological resources. The development and utilization of any part of ecological resources are likely to have an impact on other parts of the ecological resources, which is called externality. As we all know, the decision is made by the market spontaneously. The positive externality is less than the optimal number of social needs, and the negative externality will be more than the optimal number of social needs.

Mineral resources are state-owned, and the State Council, on behalf of the State, exercises the ownerships. The central and local governments are two independent entities who have conflict in the 
economic interests [8]. However, the management of ownership of mineral resources belongs to the rights of obvious conflicts between the central and local interests. The uncertainty of objects of ownership of mineral resources makes some of the rights difficult to be managed or monitored.

A rational study on ecological compensation for mineral resources in minority areas is carried out. According to the law, the mineral resources are owned by the State, and the state-owned stipulated by the laws and regulations is owned by all the people. As ethnic minorities, it is a part of the country, and each minority member is a member of all the people. For the mineral resources owned by all the people, each member of ethnic minorities has the ownership in the development of mineral resources [9]. In the distribution of developing interests of mineral resources, they are only given the right to make use of grassland or land contract and compensation for years' product revenue. While the land compensation is not enough, which does not achieve the owner's ownership.

In the early stage of the development of mineral resources, land acquisition and relocation are needed, which leads to the change of the production and life style of the minority nationalities in the development area, affects the inherent culture, and has an unexpected influence on the inheritance of language and customs. The loss of land and grassland use right, for the ethnic minorities relying on this land and grassland, what they loss is not only the right to use, but also the heritage of culture, language and customs, as well as community correlation and cultural ownership [10]. These are much deeper than the existing compensation, and the possibility for the recovery after the loss is almost zero. As a result, the legal research on compensation for mineral resources for minority areas in the development of mineral resources is more significant.

\subsection{Program design to balance the interests of all parties}

It is supposed to take the "Property Law" to stipulate and adjust the beneficial relationship between the mining enterprises and the collective land property rights owner in the exploration of mineral resources. Through the land use rights transaction between enterprise and land property owner, determine the mining fees for the use of land rent. In addition, by negotiations between mining companies and owners of mineral rights and interests, solve the loss brought about by mineral development to relevant rights owners. In the development of mineral resources, it is the first choice to solve the problem of the distribution of interests among the stakeholders through negotiation.

The system design for balancing the interests of all parties mainly contains to give the corresponding environmental rights involved in ecological compensation, including information disclosure, public participation, hearing system, public interest litigation and so on rights. Through the game and negotiation between different parities, fully express the rights of all parties and interests, and determine ecological compensation scope, standard, time limit of different area and so on important contents [11] In this way, appropriate measurements can be achieved for ecological compensation, and realize the adequate compensation. Effectively participate in decisions for the development rights, cultural rights, and language rights that are required by the ethnic minorities. Through the case analysis, view the participation degree of ethnic minorities in the ecological compensation for minority areas, so as to realize the effective participation and lay the foundation.

\section{Conclusion}

In the process of exploitation and utilization of mineral resources in ethnic areas, a series of problems are left for minority areas, including geological disasters, decline of living standards and destruction of ecological environment. The ecological compensation for mineral resources in minority areas is of great significance to the protection of the survival right, development rights and cultural rights of ethnic minorities [12]. For the continuously produced new problems in the ecological environment, in the ecological compensation mechanism, it is supposed to give priority to the particularity of minority areas, increase the weight of ethnic factors, and change the way of compensation, so as to achieve adequate and timely compensation. In the process of exploiting the resources, approaches and procedures for ethnic minorities and ethnic minority areas to effectively participate in and share the fruits of development are not perfect [13]. As a result, we first of all need to 
set up a perfect program, and through continuous negotiation by the parties, to establish and perfect the ecological compensation system. By improving the mechanism of public participation and information disclosure, encourage ethnic minorities to actively participate in the activities of the protection of rights and interests. And the procedural justice is not enough, to establish ecological compensation system through the law is a long-term stable and effective.

\section{References}

[1] Burger, J., Gochfeld, M., Bunn, A., Downs, J., Jeitner, C., Pittfield, T., ... \& Kosson, D. (2016). A Methodology to Evaluate Ecological Resources and Risk Using Two Case Studies at the Department of Energy's Hanford Site. Environmental Management, 1-16.

[2] Pellerin, B. A., Stauffer, B. A., Young, D. A., Sullivan, D. J., Bricker, S. B., Walbridge, M. R., ... \& Shaw, D. M. (2016). Emerging tools for continuous nutrient monitoring networks: sensors advancing science and water resources protection. JAWRA Journal of the American Water Resources Association.

[3] Huber, A. (2017). Protection of Traditional Ecological Knowledge Through Intergovernmental Agreements. In Collision or Collaboration (pp. 77-87). Springer International Publishing.

[4] Liu, L., de Jong, M., \& Huang, Y. (2016). Assessing the administrative practice of environmental protection performance evaluation in China: the case of Shenzhen. Journal of Cleaner Production, 134, 51-60.

[5] Hong, W., Yang, C., Chen, L., Zhang, F., Shen, S., \& Guo, R. (2017). Ecological control line: A decade of exploration and an innovative path of ecological land management for megacities in China. Journal of Environmental Management, 191, 116-125.

[6] Fontaine, K. A. (2016). Comparative Analysis of Ecological and Cultural Protection Schemes within a Transboundary Complex: The Crown of the Continent (Doctoral dissertation, University of Cincinnati).

[7] Carter, S. K., Carr, N. B., Flather, C. H., Fleishman, E., Leu, M., Noon, B. R., \& Wood, D. J. (2017). . Assessing Ecological Integrity Using Multiscale Information from Bureau of Land Management Assessment and Monitoring Programs.

[8] Peng, J., Du, Y., Liu, Y., \& Hu, X. (2016). How to assess urban development potential in mountain areas? An approach of ecological carrying capacity in the view of coupled human and natural systems. Ecological Indicators, 60, 1017-1030.

[9] Hansen, M. M., \& Rogers, S. M. (2017). Recipient of the 2016 Molecular Ecology Prize: Louis Bernatchez-advancing the conservation of aquatic resources with his contributions on the ecological genomics of adaptation and speciation. Molecular Ecology, 26(2), 413-419.

[10] Zhai, J., Zhao, Y., Li, H., Wang, Q., \& Chen, K. (2016, February). Study on the influence of ecological protection measures on water conservation capacity in the Sanjiangyuan Region. In Advances in Energy, Environment and Materials Science: Proceedings of the International Conference on Energy, Environment and Materials Science (EEMS 2015), Guanghzou, PR China, August 25-26, 2015 (p. 291). CRC Press.

[11] Liu, Q., Yang, Q., \& Niu, S. (2017). Economic Thinking on the Development of Tourism Real Estate in Poyang Lake Ecological Economic Zone. In Proceedings of the 20th International Symposium on Advancement of Construction Management and Real Estate (pp. 607-615). Springer Singapore.

[12] Bodin, Ö., Robins, G., McAllister, R., Guerrero, A., Crona, B., Tengö, M., \& Lubell, M. (2016). Theorizing benefits and constraints in collaborative environmental governance: a transdisciplinary social-ecological network approach for empirical investigations. Ecology and Society, 21(1).

[13] Yin, K., Liu, R. J., Tao, C. Y., Tang, M., Yang, Q. Y., \& Zen, F. (2017). Regional Industry Development based on the Strategy of Ecological Civilization-A Case Study of Yanqing County in Beijing. In New Energy and Sustainable Development: Proceedings of 2016 International Conference on New Energy and Sustainable Development (NESD 2016) (pp. 517-524). 
